\title{
Tax Evasion and Set Backs of the Shadow Economy in Albania
}

\section{Oltiana Muharremi}

Lecturer in Accounting and Finance, PhD student, University of Vlora, "Ismail Qemali" olta.muharremi@gmail.com

Filloreta Madani

Doc in Finance, University of Vlora, "Ismail Qemali" fcenolli@gmail.com

Erald Pelari

Lecturer in Finance, University of Vlora, "Ismail Qemali"

Doi:10.5901/mjss.2014.v5n13p398 epelari@gmail.com

\begin{abstract}
Various business enterprises operating in the informal sector of the economy are attracting more and more attention. "Cheating the government" is a thriving practice in most countries, not only for countries still in a transition of economic development, but also for countires that have e developed fiscal system. Tax and customs fraud remain a real challenge for Albania's fiscal administration. Several studies conducted in Albania prove that the degree of informal business transactions continues to be above the regional average at around $30 \%$. The tax burden is viewed, in both empirical and theoretical studies, as the main determinant of tax evasion and the shadow economy. A fundamental difficulty in analyzing tax evasion is the lack of reliable information on taxpayer compliance. The anticorruption efforts have to focus on a real reform of the administrative system, whereas the citizen's perception on corruption is mainly based on personal experiences in direct connection with the state institutions. After all, tax evasion is illegal, and individuals have strong incentives to conceal their cheating, given financial and other penalties that are imposed on individuals who are found cheating on their taxes. Both the public sector as well as the private sector should become more responsible, so that the public institutions are able to carry out their obligations under integrity conditions and without external pressure or implication. This paper gives an overview of fiscal evasion with a special focus on Albania. In particular, we concentrate on fiscal policy implications.
\end{abstract}

Keywords: Tax evasion, Corruption, Fiscal policies, Informal economy

\section{Research Objectives}

There are two main reasons for focusing on tax evasion. First of all, it is directly linked to large budget deficits and hence to lower investments in public goods. Besides being of general interest from an economic point of view, this means that the effects may differ significantly depending on the level of development of a country. This is the first major issue of interest. Second, studying tax evasion creates the opportunity to study the decision making process related to the informal sector at the individual level.

\section{Research Methodology}

Several methods have been developed to measure evasion. Even though they are all subject to imprecision and controversy, in sum they give a good picture of the dimension of tax evasion. One method involves surveys. These surveys are typically designed to elicit taxpayers' attitudes about their reporting, but such surveys can also be used to estimate non-compliance. A main advantage is that they include many socio-economic, demographic and attitudinal variables. Another research method would be to analyze information that is posted on the web from various organizations regarding tax fraud, such as the electronic bulletins of: OECD, World Bank, USAID, Albanian Statistics Institute (INSTAT), as well as the Albanian Ministry of Finance website. 


\section{Introduction}

The shadow economy comprises legal business activities that are performed outside the reach of government authorities. These activities typically fall into two categories that remain common across Europe. The first is undeclared work, which accounts for roughly two-thirds of the shadow economy. It includes wages that workers and businesses do not declare to the government to avoid taxes or documentation. Undeclared work is widespread in construction, agriculture, and household services (such as cleaning, babysitting, elderly care, and tutoring). The other one-third comes from under reporting, which is when businesses-primarily those that deal heavily in cash, such as small shops, bars, and taxis-report only part of their income to avoid some of the tax burden.

What fuels the shadow economy and what motivates to engage in it? There are four main factors:

Savings: By working outside the active economy, participants can avoid taxes and possibly social security payments, circumvent tax and labour regulations, and sidestep paperwork. A strong causal relationship exists between a country's tax rate and the size of its shadow economy. This relationship is especially pronounced during downturns.

Lack of a "guilty conscience": The shadow economy is often considered a normal part of society. This attitude is prevalent in countries where the perceived quality of state institutions and benefits is low or confidence in the state has been shaken.

Low risk of detection: Participating in the shadow economy is illegal. The chance of getting caught and being fined by the government entities is low so more individuals will consider the risk worthwhile. Thus, reducing the shadow economy requires a clear legal stance and the strength of law enforcement.

Ease of participation: Paying with cash makes it easier to engage in the shadow economy, since cash payments cannot be traced. The shadow economy is clearly a cash-based economy, and cash is the fuel that keeps the engine running.

\section{Economic Context of Albania}

Albania is a country that changed from a controlled economy during the communist regime to a democratic country with an open economy in 1990. Although the country is rich in natural resources, the economy is mainly bolstered by emigrant annual remittances, services, and the agricultural sector. In contrast to many other transition economies, macroeconomic stability in Albania in the early 1990s was followed almost immediately by a non-inflationary economic upsurge with the exception of 1996 and 1997, when Albania was faced with a major economic crisis triggered by the collapse of the pyramid investment schemes. Total liabilities of these schemes were estimated at almost 50\% of GDP in 1996. The economic impact of the crisis was severe; the Albanian lek lost half of its value. The loss of wealth in the pyramid schemes took the economy in a depression, remittances from abroad fell heavily (minus $47 \%$ ) which directly reduced investments in construction and other industries.

Table 1: Key Macroeconomic indicators

\begin{tabular}{l}
\multicolumn{1}{c}{ Indicators } \\
\begin{tabular}{|l|c|c|c|c|c|c|c|}
\multicolumn{1}{c}{ Unit } & $\mathbf{2 0 0 8}$ & $\mathbf{2 0 0 9}$ & $\mathbf{2 0 1 0}$ & $\mathbf{2 0 1 1}$ & $\mathbf{2 0 1 2}$ & $\mathbf{2 0 1 3}$ \\
\hline Population & Million (ALL) & 2.947 & 2.927 & 2.913 & 2.904 & 2.9 & 2.897 \\
\hline The average inflation rate & $\%$ & 3.4 & 2.3 & 3.6 & 3.5 & 2 & 3 \\
\hline GDP Deflator & $\%$ & 4.7 & 2 & 2.6 & 3 & 2.2 & 1.4 \\
\hline Real GDP Growth & $\%$ & 7.5 & 3.3 & 3.8 & 3.1 & 1.5 & 3.1 \\
\hline GDP & Billion (ALL) & $1,089.3$ & $1,148.1$ & $1,222.5$ & $1,297.7$ & $1,346.2$ & $1,407.0$ \\
\hline Unemployment Rate & $\%$ & 12.7 & 13.8 & 13.5 & 13.3 & 13.4 & 13.2 \\
\hline
\end{tabular}
\end{tabular}

Source: INSTAT, Albanian National Bank, Ministry of Finance, World Bank

In the period after 1998, Albania experienced rapid economic growth (real GDP growth rates of more than 7\% per year), low inflation and a stable currency. Albania continued to pursue a sustainable economic policy until 2009. The economy was able to absorb the impact of the financial crises that rippled around all international markets in 2008. The risk of the financial crises reaching the Albanian economy was far closer due to the fact that a huge number of the world's biggest economies were experiencing a full out economic crisis. Over the last 2-3 years, the effects of the global crisis have made the Albanian economy more sensitive, decreasing the GDP growth rate yearly until it reached $1.5 \%$ in 2012.

The slow decrease of GDP comes due to the close exposure the Albanian economy has with Greece and Italy. 
The main channels through which the Albanian economy is affected by developments in these countries are: demand for exports in report to remittances and foreign direct investment. In 2012 the country's economy was characterized by a slow but positive growth, stimulus fiscal policy, a relatively stable exchange rate, reduction of risk premiums, and low inflationary pressures from the demand side.

Table 2: Fiscal indicators based on a consolidated budget. Million (ALL)

\begin{tabular}{l}
\multicolumn{1}{c}{ Indicators } \\
\begin{tabular}{|l|c|c|c|c|c|c|}
\hline \multicolumn{1}{l}{$\mathbf{2 0 0 8}$} & $\mathbf{2 0 0 9}$ & $\mathbf{2 0 1 0}$ & $\mathbf{2 0 1 1}$ & $\mathbf{2 0 1 2}$ & $\mathbf{2 0 1 3}$ \\
\hline Total Revenue & 291,238 & 298,981 & 324,721 & 330,469 & 332,758 & 360,661 \\
\hline Foreign Aid & 4,228 & 4,430 & 4,605 & 3,811 & 4,020 & 11,995 \\
\hline From Taxes and Customs & 205,292 & 208,870 & 223,019 & 235,509 & 235,922 & 255,169 \\
\hline Income from Local Gov't. & 11,307 & 12,149 & 11,898 & 11,791 & 11,073 & 12,003 \\
\hline Income from special funds & 47,822 & 49,812 & 53,647 & 56,627 & 58,513 & 60,916 \\
\hline Non-tax revenue & 22,588 & 23,720 & 31,552 & 22,731 & 23,230 & 20,578 \\
\hline
\end{tabular}
\end{tabular}

The main sources of income for individuals remain: self-employment, pension and employment in the private sector. Poverty, especially in rural areas, remains a particular phenomenon. Regional differences are significant in terms of geographical distribution of industrial development zones. The Tirana-Durres region has become the most important economic center and commercial area of the country, while other regions remain behind from major developments. As is noticeable from Table 2, the majority of the budget revenue in Albania comes from taxes and customs, which constitute about 18-19\% of GDP, followed by income from special funds including income from social and health insurance by about $4-5 \%$ of GDP.

Albania as a country that has recently entered the free market economy, feels it is necessary to increase the level of income, to stabilize economic equilibrium problems and the balance of payments ultimately leading to increased economic development. Analyses show that in the country's economic performance, fiscal policy has played a leading role. For this, the design of fiscal policy always considers as an important factor the behavior of tax participants and their ability for tax-evasion.

The transition process that Albania is going through has highlighted many problems, one of which is the quality and effectiveness of fiscal policy, with the aim of creating a stable relation between its objectives and the instruments used to achieve them. In designing the fiscal policy the government has taken into consideration tax systems of developed countries, but taking into account the characteristics of less developed countries (like countries in the former communist eastern bloc) where administrative skills are limited. During the transition period, the attention is focused on expanding the tax system and its effectiveness.

The fiscal policy experience of developing and eastern European countries, recommends the use of tax incentives to encourage savings and investments. The stimulus used to promote foreign or domestic investments, to avoid risk volatility of investments, as well as increasing the speed in realizing the investment. In Albania, exemption or relief from taxes is used in the early years of development projects and programs in industry and agriculture. This stimulation should not extend beyond the limits that otherwise would not be effective and practical. The impact of such policy should be considered as a state subsidy, which has affected the income and standard of living. This requires the government to review the fiscal regime to suit the stages of implementation of the investment. Tax incentives are monitored by a law that is relatively new and is gradually improving. The main taxes overseen by this legislation are: value added tax (VAT), small business tax, corporate tax, personal income tax, property tax.

A modern tax system relies on all tax sources, but two are the most important:

\section{1- Personal Income Tax}

This type of tax constitutes the most important element of modern financial systems. Progressivity of rates and the largest number of contributors to this tax provide significant revenues for the government. Personal income tax plays an important role in sharing the tax burden by income level, realizing in this way, a distribution of national income.

\section{2- Small Business Tax}

Besides the application of a number of taxes, other important factors that constitute the entirety of public revenues are:

\footnotetext{
- Taxes

- Contributions

- Customs

- Excise Taxes
} 


\section{Administering Taxation and Taxes}

In Albania taxes and fines are administered by the tax authorities: the Directorate General of Taxation (DGT) in the Ministry of Finance and its offices in communes, municipalities and districts that depend on this department, costs for which are financed from the state budget. The fight against tax evasion is one of the primary duties of the tax administration, and should start first in the ranks of its workforce with possible links to corruption, as an offering made by dishonest taxpayers, who are trying to distort the image of tax authorities and the administration they represent. Exactly the presence of this phenomenon and its spread, naturally leads to the reduction of income taxes.

\section{The Situation of the Informal Sector in Albania}

The informal economy in Albania, according to official estimates accounts for about $30 \%$ of the total economy, while according to international financial institutions accounts $45 \%$ of the total Albanian economy. Terms: under the table work, second job, invisible, hidden, clandestine, will constitute work that is illegal and unregistered. Besides this complex of secret employment is also work performed invisibly, which takes place in a family working environment (very difficult to analyze). All these activities are not likely to be accounted for when they are in each case based on "friendly" relations and reciprocity. Under the table work is part of the informal work in the so-called "uncontrolled economy".

The decision to hide an activity can come from many factors:

$>$ The business activity operates under fiscal evasion

$>$ The business activity avoids required contributions, avoiding legal norms, or not respecting norms on working hours, and minimum wage, etc.

$>$ Activity lacks the necessary authorizations directions for further development

The black economy is a complex of activities in production, services and use of products, in order to avoid statistical records. This category includes the so-called black work as unpaid labor that is performed by the unemployed, retirees, housewives, students, and working a second job undeclared.

A special kind of gray economy is also the hidden criminal enterprises, which includes all kinds of illegal activities such as: smuggling, prostitution, gambling, drugs, and organized theft. Hidden economy and undeclared labor create in the system, a deformation in statistics directly proportional to its relative size that make less accurate the analysis of the real economic situation. The Albanian labor market has undergone major changes after 1991, economic transformation has caused substantial changes in the structure of production sectors and employment. Private sector development is done parallel to the in formalization of the economy in general and in particular illegal labor. Economic sectors where illegal employment faces relatively high levels are:

$>$ Construction Sector

$>$ Small and medium production enterprises

$>$ Service Sector

$>$ Transportation Sector

$>$ Trade

$>$ Private fishing activities, etc.

One of the sectors where it is most palpable the failure of the legislation is in the construction sector and production of building material. This sector is estimated as:

$>$ An activity that is exercised anywhere without geographical conditioning or restrictions

$>$ A profitable activity in current market conditions and has the premise for tax evasion in connection with fictitious income statements and not paying contributions

$>$ One of the sectors with the highest risk in relation to work accidents

Analysis of illegal labor or informality serves to explain the economic situation of a country and in particular the consolidation of basic state institutions, the level of its implementation, level of corruption, etc. Clearly stated informality is nothing else but fewer taxes for the state budget. So the more taxes and fees hidden and undeclared for the state, which unfairly benefit a group of people, the greater the consequences for society.

\section{Value Added Tax (VAT)}

Implementation of the VAT is a very important step towards the perfection of the fiscal system modernization. VAT as a modern, transparent and equitable tax, based on the modern system of self-declaration of taxes, to be paid through the completion of a monthly statement. The success of the deployment of VAT depends on the way the tax authorities 
organize basic functions that must perform its employees, functional connections that exist through all phases of its implementation process and the experience of other countries. Lack of motivation increases the risk of corruption for the staff directly involved in tax collection activities. Therefore modernization of tax administration should be one of the priorities.

In the tax legislation, for a violation of taxable persons in regards to VAT, there are different penalties that include fines from 10,000 Lek to 1,000,000 Lek, business closure, partial seizure of wealth and publicizing the name of the taxpayer that does not pay its dues. The main cases of violations are:

$>$ Failure to register

$>$ Registration not done in proper form

$>$ Non-issuance of an invoice

$>$ Issuance of an invoice with the wrong information

$>$ Failure of not declaring the taxes on due dates

$>$ Not declaring the correct sale price

$>$ The request for a tax credit which the tax-payer has no rights

$>$ A sales invoice issued from unregistered enterprise

$>$ Making a false or erroneous statement

$>$ Non-payment of taxes by the due date

$>$ Failure to maintain appropriate records

$>$ Non submission of records and documents upon request

$>$ Preventing or not allowing an inspection by the government authorities

Figure 1. VAT from domestic transactions by economic sector 2011-2013

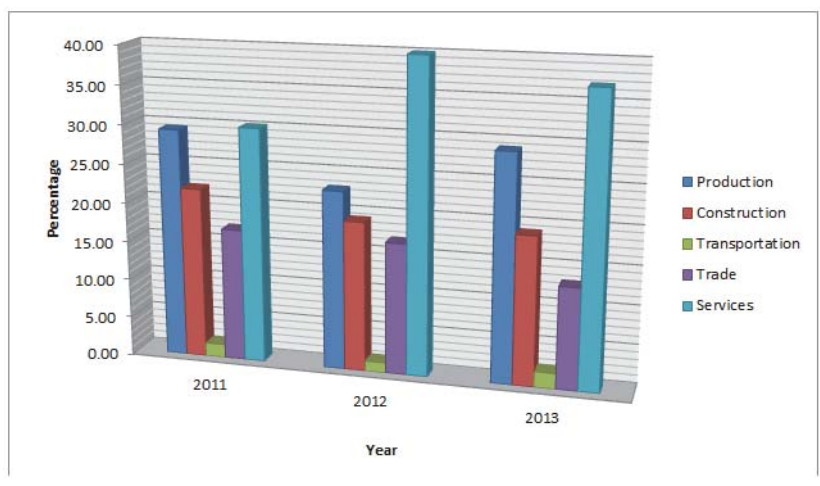

Source: Ministry of Finance

\section{Small Business Tax}

Small Business Tax is a tax on income that is applied on businesses who exercise an independent private activity that generates profits from trade, handcrafted products, various services like transportation, health, etc. This tax is calculated proportionally from income generated from the sale of services as well as fixed fees for some other services which are directly deposited in the state budget. Throughout the country there are more than 30,000 unregistered small business taxpayers and to have an effective tax system it is necessary to enroll all of them in the tax liability scheme.

Failure to register is a serious problem in tax collectors. A program to increase the value of the tax collected in the small business sector, should prioritize registration (to ensure that small businesses are inside the tax network). This group of taxpayers pays taxes based on the assessment that they themselves make and declare as income and are checked at random, due to the lack of controllers in proportion to the number of small business owners. Inspectors should be encouraged with rewards and compensation for exceptional work, in relation to tax revenues collected by the inspector. 


\section{Social Causes Enhancing Informality in Institutions}

Demographic Growth

$>$ Unemployed

$>$ Very low pensions

$>$ Very low income for households

$>$ Support of unemployment is very low

$>$ Women available for the permanent and part-time domestic work

$>$ The low efficiency of fiscal controls and other institutionalized control bodies

$>$ Limited controls by the local authorities for people who work more than one job

$>$ Work Unions do not protect their members

$>$ Law obligations in relation to formal employment are negligible

\section{Impact of Bribes and Other Crimes in Private Enterprises}

According to data published by United Nations Office on Drug and Crimes (UNODC) "BUSINESS, CORRUPTION AND CRIME IN ALBANIA" for 2013 the impact of bribery and other crimes in private businesses rank corruption as the second highest obstacle in operating a business, after the high level of taxation. In Albania, 35.7\% of bribes are paid in cash. The average amount of a bribe is about 53,000 leke, which is equivalent to 904 Euros-PPP1. About two-fifths ( $40.8 \%$ of all bribes are paid by businesses before the service, while $26 \%$ paid after the service is completed). The main purposes for paying bribes are speedy procedure (39.1\%), finalizing procedure (16.8\%), and special treatment by the authorities (7.2\%). In addition, $13.5 \%$ of paid bribes serve no immediate purpose. Percentage of proliferation of bribes paid to public officials is the highest for police officers (12.5\%), customs workers (12.3\%), tax and revenue authorities (10.7\%) and employees of municipalities and communes (10.2\%).

Prevalence of bribery shows significant differences between business sectors in Albania. Among the five sectors researched, services in accommodation and food have the highest percentage of bribery (20.3\%), followed closely by transport and storage (20.1\%), construction (18.7\%); industrial production, the supply of electricity, gas and water (14.1\%) while wholesale and retail trade have the lowest percentage of bribery at $14.1 \%$. Compared with regional averages by economic sector, all sectors in Albania have significantly higher spread rates of bribery. Accommodation (20.3 versus 9\%), transport (20.1 versus 9.9\%) and construction (18.7 versus $12.2 \%)$ have a percentage that is significantly higher than the regional average, while industrial production (14.1 vs. 9.2\%) and trade (14 versus 10.3\%) have a rate that is somewhat closer to the regional average.

Figure 2. Prevalence of bribery by economic sectors in Albania and the region of Western Balkans (2012)

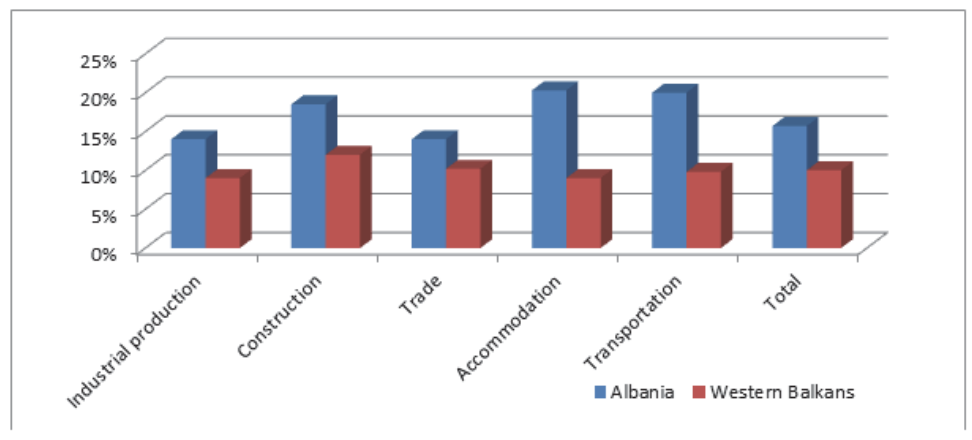

Source: UNODC. Business, corruption and crime in Albania: Impact of bribery and other crimes in private enterprises in 2013

${ }^{1}$ EU-27 Purchasing power parity of the euro (EUR-PPP) used to make the amounts given in national currencies included in the survey comparable internationally. 
Change in the proliferation of bribery by economic sector exerts direct influence on the calculation of the percentage of bribery spreading nationally. Figure 2 shows the basic composition of bribes paid in five economic sectors in Albania. Wholesale and retail trade sector constitutes the largest share (62.7\%) of bribes paid, due to the fact that this sector constitutes the largest business sector in Albania at 43.8\%.

\section{The Shadow Economy in Europe}

The size of the shadow economy in Europe reached a 10-year low in 2013, and is now estimated at $€ 2.15$ trillion. On average across Europe, the shadow economy is as large as 18.5\% of economic activity. Almost two-thirds of the shadow economy is concentrated in Europe's five largest economic powers-Germany, France, Italy, Spain, and the United Kingdom. However, in Eastern Europe the shadow economy is much larger in relation to the size of the official economy than in Western Europe. In Austria and Switzerland, the shadow economy equals roughly $7 \%$ to $8 \%$ of the size of those countries' official GDP, compared to Poland, which has a shadow economy of $€ 95$ billion, compared to an estimated GDP of $€ 400$ billion, or $24 \%$. In Eastern European nations such as Bulgaria, Croatia, Lithuania, and Estonia, the shadow economy is almost $30 \%$ the size of the official economy.

The economic crisis that began in 2008 confirms that in 2009, the first full year of impact, the shadow economy surged $0.5 \%$ relative to GDP. Figure 3 juxtaposes the development of the shadow economy in absolute euro terms with its size relative to GDP. Although the 2009 increase may not have been massive, it broke a steady long-term trend in which Europe's shadow economy declined in comparison to GDP. The accompanying reduction in the absolute size of the shadow economy is compelling evidence of the depth of the continent's economic decline. While more individuals sought alternatives to the official economy, the shadow economy could not compensate for the decline in the real economy. Improving economic conditions since 2010 have helped recover this lost ground.

Figure 3: The Shadow Economy in Europe

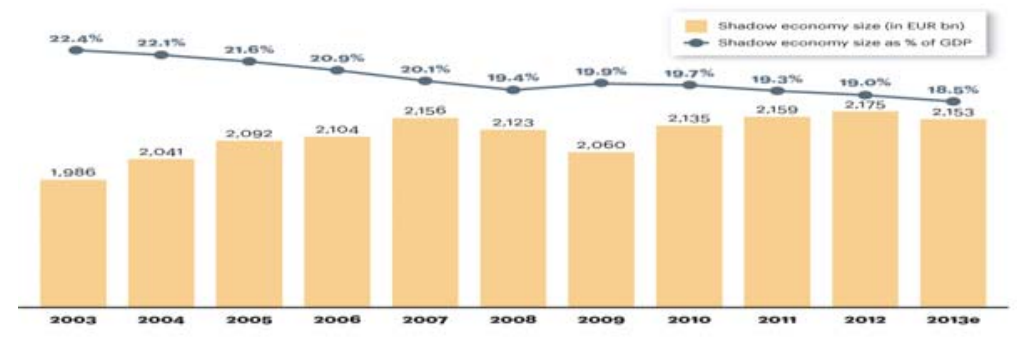

Source: Friedrrich Schneider, Johannes Kepler, University of Linz Austria, A.T. Kearney analysis.

By 2011, the shadow economy was below pre-crisis levels, and in 2013 the shadow economy is expected to shrink to an all-time low level relative to GDP. The size of this improvement, however, will depend on the speed and degree of economic recovery in the second half of the year.

\section{Cost of Comparative Analysis of Tax Abuse between Albania and the Region as Well as Other Countries}

USA has the highest loss to tax evasion of any other country in the world. In most countries total losses to tax evasion are bigger than the amount spend on healthcare. More than $1 \$$ in every $6 \$$ is not subject to tax precisely because those earning it deliberately ensured that it would be hidden from the world's tax authorities. The ratio is higher in Europe, where the shadow economy in which tax evasion takes place represents more than 1euro in every 5 euro. There are states like Greece and Italy, where economic collapse looks likely and where the threat to the stability of both European and global economies is centered, that ratio is worse, more than 1 euro in 4 euro is the shadow economy in these countries.

Tax evasion is always a crime. By definition, tax evasion is illegal, while tax avoidance by definition does not technically break the law. Tax evasion becomes both a crime against society and democracy. That is because both societies and democracy can fail as economies falter when the demands for government services increase in times of 
economies crises and the people willing to make payments for them are too few in number, as consequence tax evasion is at the core of the crisis in the world's economies.

According to a report published by the Tax Justice Network which has made a survey for 145 countries:

$>$ Total tax evasion in excess of US $\$ 3.1$ trillion, or $5.1 \%$ of global GDP, is due to activity in the shadow economy.

$>$ Only a minority part of this is due to tax havens.

$>$ Total healthcare spending worldwide amounted to $\$ 5.7$ trillion. Tax evasion cost, on average, $54.9 \%$ of healthcare spending.

$>$ The un-weighted average rate of tax evasion to healthcare spending is $110 \%$.

As is seen from the table below "The Cost of Tax Abuse", Albania is ranked 93 in the world, having Size of the Shadow Economy at a level of $34.3 \%$, comparable with countries in this region ranging from Italy at $27 \%$ Italy to Macedonia at 37.5\%. Government spending as \% of GDP in Albania is 32.3\%, low value compared to the other countries surveyed. Shadow Economy as \% of healthcare spending in Albania is $123 \%$, while the un-weighted average rate of tax evasion to healthcare spending for over 145 countries was in fact 110\%. Total losses to tax evasion are bigger than the amount spent on healthcare.

Table 3. The Cost of Tax Abuse

\begin{tabular}{|c|c|c|c|c|c|c|c|c|c|c|c|c|c|}
\hline \multicolumn{14}{|c|}{ The Cost of Tax Abuse } \\
\hline \multirow[t]{2}{*}{$\begin{array}{l}\text { Record } \\
\text { Number }\end{array}$} & \multirow[t]{2}{*}{ Country } & GDP & Population & $\begin{array}{c}\text { GDP per } \\
\text { head of } \\
\text { population }\end{array}$ & $\begin{array}{l}\text { Size of } \\
\text { Shadow } \\
\text { Economy }\end{array}$ & $\begin{array}{c}\text { Tax } \\
\text { burden } \\
\text { overall } \\
\%\end{array}$ & $\begin{array}{l}\text { Gov't } \\
\text { spending } \\
\text { as \% of } \\
\text { GDP }\end{array}$ & $\begin{array}{l}\text { Health } \\
\text { care } \\
\text { spending } \\
\text { as \% of } \\
\text { GDP }\end{array}$ & $\begin{array}{l}\text { Size of } \\
\text { Shadow } \\
\text { Economy }\end{array}$ & $\begin{array}{l}\text { Tax lost as } \\
\text { a result of } \\
\text { Shadow } \\
\text { Economy }\end{array}$ & $\begin{array}{l}\text { Total health } \\
\text { care } \\
\text { spending }\end{array}$ & \begin{tabular}{|c|} 
Shadow \\
Economy as \\
$\%$ of \\
healthcare \\
spending \\
\end{tabular} & $\begin{array}{l}\text { Cost of tax } \\
\text { evasion, } \\
\text { local } \\
\text { currency }\end{array}$ \\
\hline & & US \$ mil & & $\$$ & $\%$ & $\%$ & $\%$ & $\$$ & US \$ mil & US \$ mil & US \$ mil & \begin{tabular}{|l|}
$\%$ \\
\end{tabular} & $m$ \\
\hline 1 & USA & $14,582,400$ & $312,582,000$ & 46,651 & 8.6 & 26.9 & 38.9 & 15.2 & $1,254,086$ & 337,349 & $2,216,525$ & 15 & 0 \\
\hline 2 & Brazil & $2,087,890$ & $190,755,799$ & 10,945 & 39 & 34.4 & 41 & 8.7 & 814,277 & 280,111 & 175,383 & 160 & 481,791 \\
\hline 3 & Italy & $2,051,412$ & $60,705,991$ & 33,793 & 27 & 43.1 & 48.8 & 4.8 & 553,881 & 238,723 & 178,473 & 134 & 183,817 \\
\hline 4 & Russia & $1,479,819$ & $142,914,136$ & 10,355 & 43.8 & 34.1 & 34.1 & 10.5 & 648,161 & 221,023 & 71,031 & 311 & $6,940,116$ \\
\hline 5 & Germany & $3,309,669$ & $81,724,000$ & 40,498 & 16 & 40.6 & 43.7 & 11.2 & 529,547 & 214,996 & 347,515 & 62 & 165,547 \\
\hline 6 & France & $2,560,002$ & $65,821,885$ & 38,893 & 15 & 44.6 & 52.8 & 8.3 & 384,000 & 171,264 & 286,720 & 60 & 131,873 \\
\hline 21 & Greece & 304,865 & $10,787,690$ & 28,260 & 27.5 & 35.1 & 46.8 & 10.1 & 83,838 & 29,427 & 30,791 & 96 & 22,659 \\
\hline 36 & Romania & 161,624 & $21,436,000$ & 7,540 & 32.6 & 28.5 & 37.6 & 5.4 & 52,689 & 15,016 & 8,728 & 172 & 49,404 \\
\hline 74 & $\begin{array}{c}\text { Bosnia and } \\
\text { Herzegovina }\end{array}$ & 16,888 & $3,843,126$ & 4,394 & 33.6 & 37.6 & 50.3 & 10.3 & 5,674 & 2,134 & 1,739 & 123 & 3,200 \\
\hline 93 & Albania & 11,786 & $3,194,972$ & 3,689 & 34.3 & 24.3 & 32.3 & 6.8 & 4,043 & 982 & 801 & 123 & 104,483 \\
\hline 94 & Macedonia & 9,118 & $2,057,284$ & 4,432 & 37.6 & 28.4 & 34.5 & 6.8 & 3,428 & 970 & 620 & 156 & 44,436 \\
\hline
\end{tabular}

Source of data see "The Cost of Tax Abuse" briefing, November 2011

\section{How to Combat Shadow Economy?}

Figure 4 illustrates the two primary areas in which authorities have fought the shadow economy. The first are general measures to address the shadow economy directly; these have historically been the prevailing tactics, and they have seen an additional boost during the downturn. These include first and foremost rules, controls, and penalties, along with the strengthening of human and technical capabilities to ensure law enforcement. Reducing red tape, especially by simplifying tax forms and enabling electronic submission, has become ubiquitous; meanwhile, providing incentives for not participating in the shadow economy through the material advantage of lower taxes and social security contributions, or by creating a guilty conscience has dropped in priority. Fostering financial inclusion and thus reducing the size of the shadow economy as more people have access to banks. 
Figure 4. Addressing the shadow economy through direct measures and cash displacement.

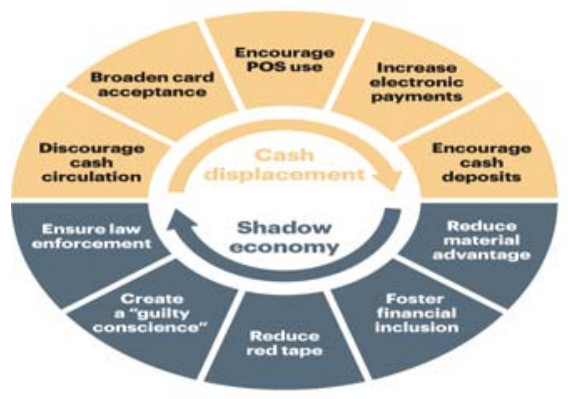

Source: A.T. KEARNEY analysis

The second area of measures, cash displacement, is more complex, since it means changing habits and coordinating actions among many stakeholders, including governments, banks, payment providers, and merchants. Planned initiatives must build on one another to ensure improvement, starting with creating the infrastructure and ending with rewarding consumers for using non-cash options. We have identified several ways that electronic payments can encourage cash displacement and help reduce the shadow economy.

Discourage cash circulation - Easy access to cash, particularly with no-fee automated teller machines (ATMs), slows down the transition to electronic transactions.

Encourage POS uses - Most day-to-day transactions, especially those worth less than €15, are cash-based. Creating incentives for individuals to use their cards in these situations is an easy way to change behavior.

Increase electronic payment - In any economy, governments are among the largest initiators and recipients of payments, and they can serve as role models by adopting electronic payments. Governments have many options, including mandating that salary payments for public sector workers are made to checking accounts, that unemployment benefits or pensions are distributed to prepaid cards, that taxes and fines are paid online, and that cards or money transfers are used for all public sector purchases.

\section{Conclusions and Findings}

Tax evasion is a serious problem, not only for economic development countries still in transition, but also in countries that have a developed fiscal system. Fiscal evasion is a behavior, which is in contrast with the previously established rules for specific fiscal provisions, that foresees administrative fine as well. It is a violation of law nonpayment of predetermined taxes. Tax avoidance is not against the law, it consists a business, which is conducted in a legal way, in order to avoid creating a taxable base, thus reducing tax liability.

The biggest losers are the ordinary citizens of the informal economy, because the informality inhibits long-term economic growth and productivity increases; creates unfair competition; hampers the growth of small and medium-sized (the main sources of employment); and leaving millions of workers without basic rights, such as health insurance and pensions. Also entails a significant loss of tax revenue, reducing both the quality and quantity of public services. Inevitably also increase income inequality and social injustice.

\section{The Causes of Tax Evasion}

The causes of tax evasion are complex and difficult to detect. If all causes of fiscal evasion would I be totally understood, an optimistic view would be created leading to its elimination or reduction in a less alarming size.

\section{Organizational structure and functionality}

It is important to recruit personnel for inspection and tax assessment. These activities can be improved by increasing the quantitative and qualitative abilities of the personnel.

2. Legislative System

Instability in the setting of laws leads to a continuous chaos in administrative provisions, in addition to creating serious problems for the adequate modernization of a professional working staff. It also leads to the deterioration of links 
between taxpayers and revenue service, due to the great difficulty of knowing the exact time and deadlines to fulfill tax obligations.

\section{Balance of tax claims}

Even if all legal proceeding ended, it typically takes 10 years for a final court decision.

4. International legal framework

The current international legal framework, especially the European Economic Community, compels us to verify the existence of significant differences in tax burden.

\section{Tax Burden}

There are different opinions in Albania about the size of the tax burden. There are those who think that this burden is high and those who think that the tax burden is unsustainable, given the current level of development.

\section{The Consequences of Tax Evasion}

Tax evasion causes difficulty in financing the planned expenditure. The main principle of collecting taxes and fees in general is for the public interest. So a shortfall in public revenues means less investment in infrastructure, little investment in education, cultural activities, science research, healthcare, etc., a reduction of public goods in general is detrimental to society. Regarding the fight against tax evasion, it is important to specify that tax evasion depends on two factors:

1. Efficiency of public administration

2. Profit made by avoiding tax contributions

The Ministry of Finance has a defiant task not easy to implement tax simplification because it needs to clearly define its strategies, possible loopholes and limits, which can operate to benefit the government whose primary duty is to fight tax evasion. Avoiding concealment of revenues from private enterprises there must be an efficient cooperation between the financial administration, tax inspectors, and authorities through the timely exchange of data necessary for making the necessary checks and required the establishment of a desirable control structure. Special care and importance should be given to taxation policies that apply to the country. The tax system must be characterized by fairness in taxation.

\section{Recommendations for Reducing the Level of Informal Economy}

1. Reducing the informal economy seems like a national duty, therefore requires government intervention and action. Governments can intervene by reducing fiscal pressure, thus facilitating the tax system and reducing costs associated with regulatory compliance, strengthening the implementation of new standards, etc. The government should also eliminate barriers to competition, improving business registration processes, increase transparency of public procurement and improve access to borrowing money. This is because the complex rules for licensing, for the labor market and bureaucratic barriers raise the informal economy.

2. Statistically countries with lower taxes tend to have a lower level of informal economy. Tax breaks only stabilizes the informal economy but does not reduce it, and therefore the tax system should be improved with simple taxes in general, logical for citizens and applicable in terms of the Albanian economy. Building bridges between contributors and benefits from the fiscal system, seen as the main way that encourages citizens and businesses to cooperate in the formal economy

3. Continuously strengthening state institutions increase their confidence to remain public roads safer for an extension to the formalization of the economy and the constant reduction of its informal sector.

4. Countries with more corruption have higher informal economy. The fight against corruption, understood as strengthening and consolidation of state institutions, as civic consciousness and individual accountability increases, and strengthening and modernization of public administration remain premise that this sector come gradually diminishing.

\section{References}

Allingham, M. G., \& Sandmo, A. (1972). Income tax evasion: A theoretical analysis. Journal of Public Economics, 1 (3-4), 323-338.

Bank of Albania. (2008, 2009, 2010, 2011, 2012) Annual Reports.

Bernasconi, M and Zanardi, A. (2004). Tax evasion, tax rates and reference dependence. FinanzArchiv, 60 (4), $422-445$.

Braithwaite, V. (2009). Defiance in Taxation and Governance - Resisting and Dismissing Authority in a Democracy. Cheltenham, UK and Northampton, MA: Edward Elgar Publishing.

Bird, R.M. and E. M. Zolt. (2005) "Redistribution via Taxation: The Limited Role of the Personal Income Tax in Developing Countries," 
UCLA Law Review.

European Economy, 2006 Economic and Fiscal Programs of potential countries, by Directorate General for Economic and Financial Affairs, February 2007.

Fiscal Policy and Economic Growth: Lessons for Eastern Europe and Central Asia.

Fatbardha Kadiu "Albania Fiscal Policy: Designing Tax Policy by Given Circumstances" Mediterranean Journal of Social Sciences Vol. 3 (1) January 2012

Fortin, B., G. Lacroix, and M.-C. Villeval (2007). "Tax evasion and social interaction", Journal of Public Economics, 91 (8), $2089-2112$.

Gërxhani Klarita, Schram Arthur, Tax Evasion and Source of Income : An Experimental Study in Albania and Netherlands, October 2001.

"The Cost of Tax Abuse" A briefing paper on the cost of tax evasion worldwide, The tax Justice Network. November 2011

The Shadow Economy In Europe 2013. ATKearney. Friedrich Schneider

Schneider, F., \& Enste, D. H. (2002). The Shadow Economy - An International Survey. Cambridge, MA: Cambridge University Press).

UNODC, 2013. Biznesi, korrupsioni dhe krimi në Shqipëri: Ndikimi i ryshfetit dhe krimeve të tjera në ndërmarrjet private.

Wintrobe R. Gërxhani K. 2004 "Tax evasion and trust: A comparative analysis" Proceedings of the Annual Meeting of the European Public Choice Society - EPCS

World Bank. (2008, 2009, 2010, 2011) Annual Report.

World Bank Policy Research Working Paper No. 5356 . Friedrich Schneider, Andreas Buehn and Claudio E. Montenegro. July 2010. 